\title{
Copper(I) mediated oligomerisation of a phosphaalkyne $\dagger$
}

\author{
Ulf Vogel, ${ }^{a}$ John F. Nixon ${ }^{b}$ and Manfred Scheer*a \\ Received (in Cambridge, UK) 7th August 2007, Accepted 14th September 2007 \\ First published as an Advance Article on the web 28th September 2007 \\ DOI: $10.1039 / \mathrm{b} 712161 \mathrm{j}$
}

The oligomerisation of tert-butylphosphaalkyne, ${ }^{t} \mathrm{BuC} \equiv \mathrm{P}$, mediated by $\mathrm{Cu}(\mathrm{I})$ complexes yields an unprecedented $\mathrm{C}_{4} \mathrm{P}_{5}$ cage compound, which is stabilised in a matrix of copper(I) iodide.

Following the successful isolation of tert-butylphosphaalkyne 1 by Becker et $a l^{1}{ }^{1}$ the first compound featuring a carbon-phosphorus triple bond which is stable at room temperature, its coordination chemistry $^{2,3}$ as well as its element organic chemistry ${ }^{3,4}$ has been widely explored. One focus of these explorations was the oligomerisation of $\mathbf{1}$, since this reaction yields a range of novel carbon-phosphorus cage compounds, often stereoselectively. ${ }^{5}$ The oligomerisation of $\mathbf{1}$ can be induced by a variety of methods, such as thermal activation and reactions with Lewis acids. For the latter strategy, which often proceeds in a more controlled fashion than thermal oligomerisation, both main group and transition metal Lewis acids have been used. ${ }^{6}$ The resulting carbon-phosphorus cage compounds feature multiple phosphorus atoms that can act as coordination sites for transition metals. ${ }^{7}$ This suggested to us that the rigid cages could act as building blocks for supramolecular aggregates. Our group has recently synthesised a variety of supramolecular aggregates using group 10 metals and $\mathrm{P}_{n}$-ligand complexes as building blocks, ${ }^{8}$ so it was of interest to see if the function of the latter could possibly also be fulfilled by carbonphosphorus cage compounds. Since we previously successfully used the Lewis acidic copper(I) halides for the synthesis of supramolecular assemblies, we decided to explore the reactivity of 1 with similar complexes. It can be expected that the metal halide serve as both a Lewis acid to initiate the oligomerisation of $\mathbf{1}$ and at the same time function as a supramolecular matrix ${ }^{9}$ to stabilise any resulting unusual carbon-phosphorus cages.

The reaction of tert-butylphosphaalkyne 1 with $\mathrm{CuI}$ in $\mathrm{CH}_{3} \mathrm{CN}$ leads to the formation of a red solution, which shows a singlet in its ${ }^{31} \mathrm{P}\left\{{ }^{1} \mathrm{H}\right\}$ NMR spectrum at $-58.1 \mathrm{ppm}$. This value is shifted downfield in comparison to free $\mathbf{1}\left(\delta=-68.0 \mathrm{ppm}\right.$ in $\left.\mathrm{C}_{6} \mathrm{D}_{6}\right)$ which indicates an initial complexation of $\mathbf{1}$ by the copper(I) halide. After two days a solid which precipitated out of the solution, was obtained as small needle shaped crystals if the reaction solution is not agitated. This crystalline material was identified as $\left[\mathrm{H}\left({ }^{\mathrm{t}} \mathrm{BuC}\right)_{4} \mathrm{P}_{5}(\mathrm{CuI})_{3}\left(\mathrm{CH}_{3} \mathrm{CN}\right)_{x}\right]_{n}(x=1,3)\left(2 \cdot x \mathrm{CH}_{3} \mathrm{CN}\right)$ by singlecrystal X-ray structure determinations.§ During several different attempts to repeat the reaction we occasionally obtained small

\footnotetext{
${ }^{a}$ Universität Regensburg, Institut für Anorganische Chemie, 93040, Regensburg, Germany.E-mail: manfred.scheer@chemie.uniregensburg.de; Fax: +49 941943 4439; Tel: +49 9419434440 ${ }^{b}$ Chemistry Department, School of Life Sciences, University of Sussex, Falmer, Brighton, UK BN19QJ

$\uparrow$ Electronic supplementary information (ESI) available: Experimental details for the removal of $\mathrm{CuI}$ from 2 and the ${ }^{31} \mathrm{P}$ NMR data of the resulting products. See DOI: 10.1039/b712161j
}

amounts of red crystals as a side product which was identified as $\left[\left({ }^{\mathrm{t}} \mathrm{BuCP}\right)_{4} \mathrm{Cu}_{2} \mathrm{I}_{2}\right]_{2}(\mathbf{3})$.

Complexes $\mathbf{2}$ and $\mathbf{3}$ are insoluble in common organic solvents which made it impossible to investigate their NMR spectroscopic properties.

The crystal structure of $\mathbf{2} \S$ is depicted in Fig. 1 and 2. It shows a novel ${ }^{t} \mathrm{Bu}_{4} \mathrm{C}_{4} \mathrm{HP}_{5}$ cage that coordinates to three $\mathrm{CuI}$ units of a ladder-like motif, in such a way that a one-dimensional coordination polymer is obtained. The polymeric strands are oriented along the crystallographic $c$-axis. The ${ }^{t} \mathrm{Bu}_{4} \mathrm{C}_{4} \mathrm{HP}_{5}$ cage in 2 (Fig. 1) has not been previously observed as an oligomer of $\mathbf{1}$. Since the composition of the cage molecule is not a multiple of the phosphaalkyne $\mathbf{1}$ it is obvious that the stoichiometry of the cage cannot be described by a simple oligomerisation of $\mathbf{1}$. We assume that the cage was formed by an initial pentamerisation reaction of $\mathbf{1}$ followed by the elimination of a $t \mathrm{BuC}$ moiety, which probably was caused by the steric crowding in the $\mathrm{CuI}$ matrix, and a subsequent protonation of the vacant coordination site. The cage structure in $\mathbf{2}$ can be described as a $\mathrm{P}_{5} \mathrm{C}_{3}$ cubane where a $\mathrm{CH}^{\mathrm{t}} \mathrm{Bu}$ unit is inserted into a $\mathrm{P}-\mathrm{P}$ bond. All bonds in the cage are in the

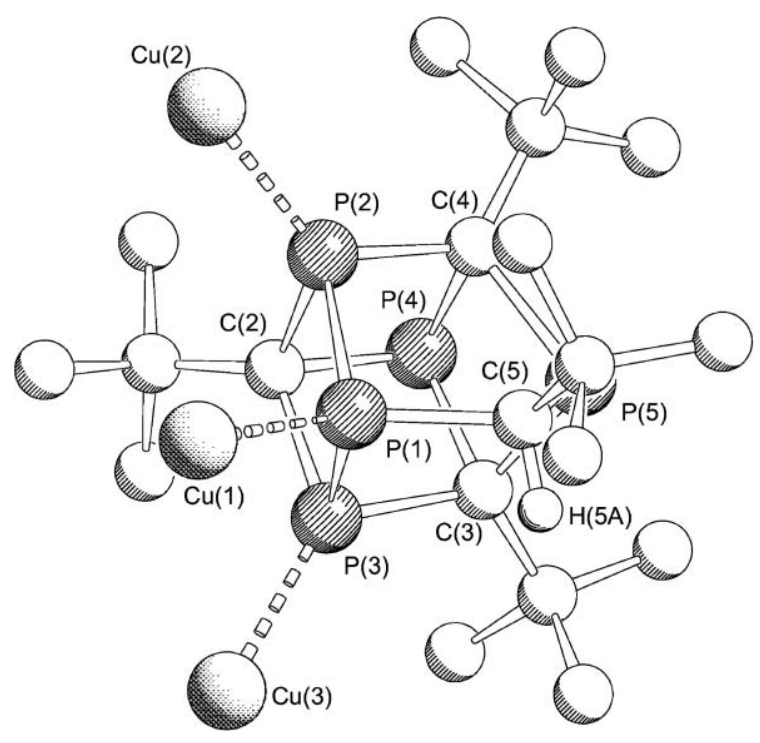

Fig. $1 \mathrm{C}_{4} \mathrm{P}_{5}$ cage of 2 showing the coordination mode to the copper atoms. Hydrogen atoms at the tert-butyl substituents have been omitted for clarity. Selected bond lengths $(\AA)$ and angles $\left({ }^{\circ}\right)$ : $\mathrm{Cu}(1)-\mathrm{P}(1) 2.259(3)$, $\mathrm{Cu}(2)-\mathrm{P}(2)$ 2.230(3), $\mathrm{Cu}(3)-\mathrm{P}(3)$ 2.256(3), $\mathrm{P}(1)-\mathrm{P}(2)$ 2.233(4), $\mathrm{P}(1)-\mathrm{P}(3)$ 2.193(5), $\mathrm{P}(1)-\mathrm{C}(5)$ 1.854(10), $\mathrm{P}(2)-\mathrm{C}(2)$ 1.897(10), $\mathrm{P}(2)-\mathrm{C}(4)$ 1.852(9), $\mathrm{P}(3)-\mathrm{C}(2) 1.912(9), \mathrm{P}(3)-\mathrm{C}(3)$ 1.901(10), $\mathrm{P}(4)-\mathrm{C}(2) 1.875(10), \mathrm{P}(4)-\mathrm{C}(3)$ 1.923(10), $\mathrm{P}(4)-\mathrm{C}(4)$ 1.971(10), $\mathrm{P}(5)-\mathrm{C}(3)$ 1.891(12), $\mathrm{P}(5)-\mathrm{C}(4)$ 1.943(11), $\mathrm{P}(5)-\mathrm{C}(5)$ 1.830(10); $\mathrm{Cu}(1)-\mathrm{P}(1)-\mathrm{P}(2)$ 114.1(1), $\mathrm{Cu}(1)-\mathrm{P}(1)-\mathrm{P}(3)$ 114.3(2), $\mathrm{Cu}(1)-\mathrm{P}(1)-\mathrm{C}(5)$ 136.2(4), $\mathrm{P}(2)-\mathrm{P}(1)-\mathrm{P}(3)$ 81.5(2), $\mathrm{P}(2)-\mathrm{P}(1)-\mathrm{C}(5)$ 99.9(3), $\mathrm{P}(3)-\mathrm{P}(1)-\mathrm{C}(5)$ 96.8(4), $\mathrm{Cu}(2)-\mathrm{P}(2)-\mathrm{P}(1)$ 112.6(2). 


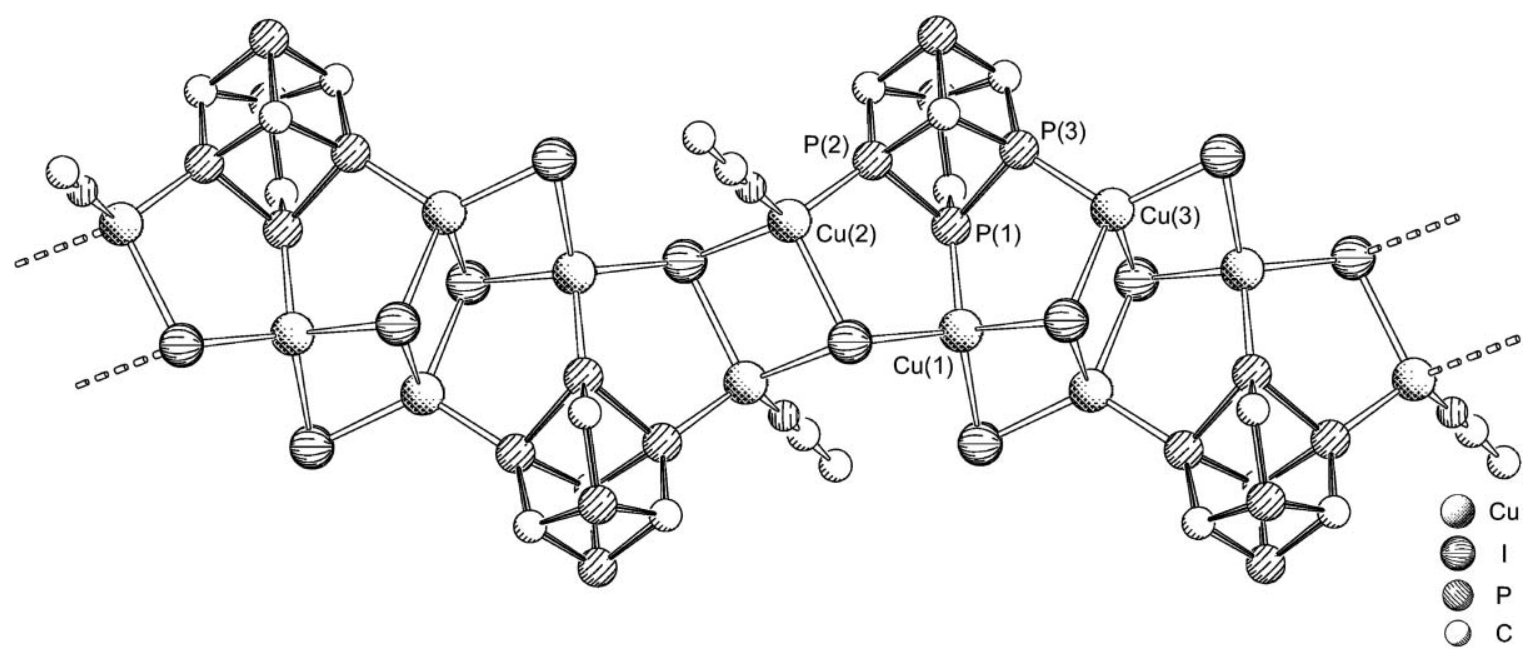

Fig. 2 Polymeric strand in 2 oriented along the crystallographic $c$-axis; tert-butyl groups and protons have been omitted for clarity.

range of normal single bonds. The high strain within the cage is reflected in bond angles at the carbon atoms which can be as acute as 87.7(5) for $\mathrm{P}(4)-\mathrm{C}(4)-\mathrm{P}(5)$. Coordination of the $\mathrm{C}_{4} \mathrm{P}_{5}$ cage to three copper atoms is achieved via the $\mathrm{P}$ atoms $\mathrm{P}(1), \mathrm{P}(2)$ and $\mathrm{P}(3)$. The copper atoms $\mathrm{Cu}(1)$ and $\mathrm{Cu}(3)$ are included in ladder-like $\mathrm{Cu}_{4} \mathrm{I}_{4}$ units, $\mathrm{Cu}(2)$ is part of a $\mathrm{Cu}_{2} \mathrm{I}_{2}$ ring. These subunits are connected in such a way that a one-dimensional polymeric strand is formed (Fig. 2). All copper atoms show a tetrahedral coordination environment and the bond lengths in the CuInetwork are within normal ranges.

The molecular structure of $\mathbf{3}$, which has a crystallographically imposed inversion symmetry, is depicted in Fig. 3 and consists of a $\mathrm{C}_{4} \mathrm{P}_{4}$ cage which was already spectroscopically described as an uncoordinated cage by Regitz and co-workers as the product of a reaction sequence starting with the oligomerisation of $\mathbf{1}$ induced by

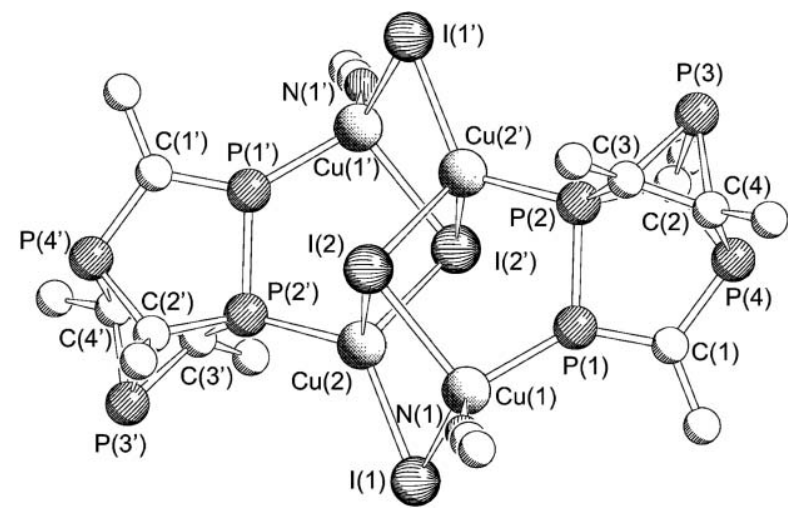

Fig. 3 The molecular structure of 3; hydrogen atoms and methyl groups at the tert-butyl groups have been omitted for clarity. Symmetry code: $2-x, 2-y,-z$. Selected bond lengths $(\AA)$ and angles $\left({ }^{\circ}\right)$ : I(1)$\mathrm{Cu}(1) \quad 2.599(2), \quad \mathrm{I}(1)-\mathrm{Cu}(2) \quad 2.587(1), \quad \mathrm{I}(2)-\mathrm{Cu}(1) \quad 2.739(2), \quad \mathrm{I}(2)-\mathrm{Cu}(2)$ 2.725(2), I(2)-Cu(2') 2.704(2), $\mathrm{Cu}(1)-\mathrm{P}(1)$ 2.233(3), $\mathrm{Cu}(1)-\mathrm{N}(1)$ 2.017(8), $\mathrm{Cu}(2)-\mathrm{P}\left(2^{\prime}\right)$ 2.256(3), $\mathrm{P}(1)-\mathrm{C}(1)$ 1.693(9), $\mathrm{P}(1)-\mathrm{P}(2)$ 2.180(3), $\mathrm{P}(2)-\mathrm{C}(2)$ 1.842(9), $\mathrm{P}(2)-\mathrm{C}(3)$ 1.863(10), $\mathrm{P}(3)-\mathrm{C}(2)$ 1.956(9), $\mathrm{P}(3)-\mathrm{C}(3)$ 1.905(10), $\mathrm{P}(3)-\mathrm{C}(4) \quad 1.897(10), \mathrm{P}(4)-\mathrm{C}(1)$ 1.862(9), $\mathrm{P}(4)-\mathrm{C}(2)$ 1.840(9), $\mathrm{P}(4)-\mathrm{C}(4)$ 1.889(10), C(3)-C(4) 1.578(10); $\mathrm{Cu}(1)-\mathrm{I}(1)-\mathrm{Cu}(2)$ 69.77(5), Cu(1)-I(2)$\mathrm{Cu}(2)$ 65.77(4), $\mathrm{Cu}(1)-\mathrm{I}(2)-\mathrm{Cu}\left(2^{\prime}\right)$ 93.90(4), $\mathrm{Cu}(2)-\mathrm{I}(2)-\mathrm{Cu}\left(2^{\prime}\right)$ 84.58(5), $\mathrm{I}(1)-\mathrm{Cu}(1)-\mathrm{I}(2)$ 107.96(5), I(1)-Cu(1)-P(1) 119.44(8).
$\mathrm{AlCl}_{3}{ }^{10}$ In 3 two of these cages are coordinated to a ladder-like $\mathrm{Cu}_{4} \mathrm{I}_{4}$ unit, which is terminated by two molecules of $\mathrm{CH}_{3} \mathrm{CN}$. All bonds within the cage compound can be described as single bonds, except the bond between $\mathrm{C}(1)$ and $\mathrm{P}(1)$ (1.693(9) $\AA$ ) which is formally a double bond.

To test if the method of $\mathrm{Cu}(\mathrm{I})$ assisted self assembly of $\mathbf{1}$ can be used as a synthetic method for the preparation of free carbon phosphorus cages, we tried to remove the metal atoms from the cage. $\mathrm{Cu}(\mathrm{I})$ halides are known to form very stable cyano complexes and the method to extract $\mathrm{CuI}$ from a phosphorus adduct was recently imaginatively used to obtain a new allotrope of phosphorus. $^{11}$ Indeed, if $\mathbf{2}$ is suspended in a mixture of an aqueous $\mathrm{NaCN}$ solution and $\mathrm{Et}_{2} \mathrm{O}$, after $5 \mathrm{~h}$ all of the orange powder has dissolved and the ether phase shows a pale yellow colour ( $c f$. ESI $\dagger$ ). The ${ }^{31} \mathrm{P}$ NMR spectrum of the $\mathrm{Et}_{2} \mathrm{O}$ phase is complex and can be attributed to three major products, one of the them being the expected free $\mathrm{C}_{4} \mathrm{P}_{5}$-cage $\mathbf{4}$ (Scheme 1) found in $\mathbf{2}$. Its ${ }^{31} \mathrm{P}$ NMR spectrum shows five multiplets in a range from 190 to $-33 \mathrm{ppm}$ with a coupling pattern that can be assigned to the free cage 4 (see ESI $\dagger$ ). Unexpectedly, the spectrum also showed signals attributable to two other carbon-phosphorus compounds, which could be identified as 5 and $\mathbf{6}$ by their ${ }^{31} \mathrm{P}$ NMR spectra (Scheme 1). Binger et al. obtained the triphospha-Dewar-benzene 5 by a reaction of $\left(\mathrm{COT}^{\prime}\right) \mathrm{Hf}^{\mathrm{t}}\left(\mathrm{Bu}_{3} \mathrm{C}_{3} \mathrm{P}_{3}\right)$ with $\mathrm{C}_{2} \mathrm{Cl}_{6}\left(\mathrm{COT}^{\prime}=1,4-\right.$ $\left.\left(\mathrm{Me}_{3} \mathrm{Si}\right)_{2} \mathrm{C}_{8} \mathrm{H}_{6}\right)$ and the reported NMR spectroscopic data matches our observations. ${ }^{12}$ In addition to the spectroscopic identification the structure of $\mathbf{6}$ was confirmed by X-ray crystallography (Fig. 4), which has a crystallographically imposed mirror symmetry. The formation of the novel cage compound $\mathbf{6}$, which is a valence isomer of $\mathbf{4}$, gives rise to the assumption that the free cage $\mathbf{4}$

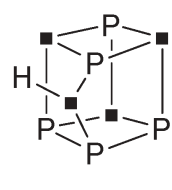

4

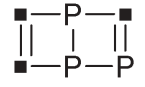

5

$$
-\mathrm{CCMe}_{3}
$$

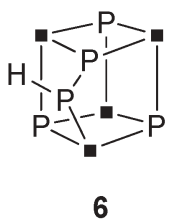

Scheme 1 Compounds 4-6. 


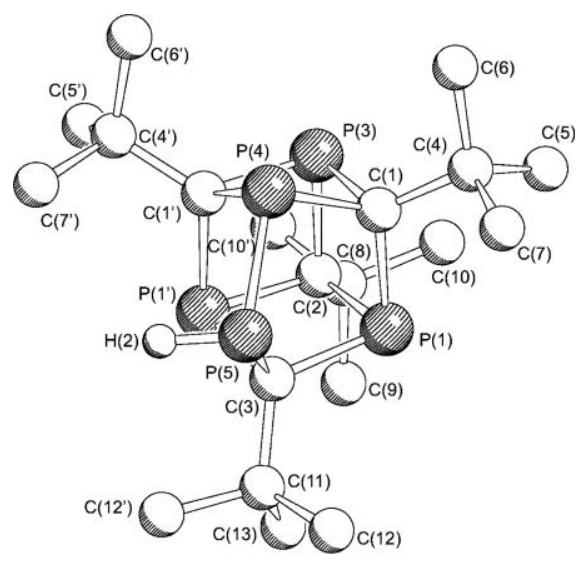

Fig. 4 Molecular structure of 6; hydrogen atoms have been omitted for clarity. Symmetry code: $x, 1-y, z$. Selected bond lengths $(\AA)$ and angles $\left.{ }^{\circ}\right)^{\circ}: \mathrm{P}(4)-\mathrm{P}(5)$ 2.157(2), $\mathrm{P}(5)-\mathrm{C}(3)$ 1.884(5), $\mathrm{P}(1)-\mathrm{C}(1)$ 1.896(4), $\mathrm{P}(1)-\mathrm{C}(2)$ 1.893(3), $\mathrm{P}(1)-\mathrm{C}(3)$ 1.895(3), $\mathrm{P}(3)-\mathrm{C}(1)$ 1.901(4), $\mathrm{P}(3)-\mathrm{C}(2)$ 1.871(5), $\mathrm{P}(4)$ $\mathrm{C}(1)$ 1.891(4), C(4)-C(1) 1.539(5), C(2)-C(8) 1.536(7), C(3)-C(11) 1.562(7); $\mathrm{C}(2)-\mathrm{P}(1)-\mathrm{C}(3) \quad 87.74(16), \quad \mathrm{P}(1)-\mathrm{C}(1)-\mathrm{P}(3) \quad 93.42(17), \quad \mathrm{C}(2)-\mathrm{P}(1)-\mathrm{C}(3)$ 87.74(16), C(2)-P(3)-C(1) 86.21(16), C(2)-P(3)-P(4) 101.90(16), C(1)$\mathrm{P}(3)-\mathrm{C}\left(1^{\prime}\right)$ 86.21(16), $\mathrm{P}(1)-\mathrm{C}(3)-\mathrm{P}\left(1^{\prime}\right)$ 91.8(2), C(1)-P(4)-C(1') 86.21(16), $\mathrm{C}(3)-\mathrm{P}(5)-\mathrm{P}(4)$ 92.88(16).

undergoes rearrangement reactions, when the $\mathrm{CuI}$ matrix is removed.

In summary we have shown that the oligomerisation of $\mathbf{1}$ in the presence of $\mathrm{CuI}$ can be used for the synthesis of new carbonphosphorus cage compounds. Preliminary investigations on the extraction of $\mathrm{CuI}$ from the insoluble supramolecular aggregates have shown that it should be possible to remove $\mathrm{CuI}$ from the reaction products and isolate the free cage compounds, which partially undergo subsequent transformation, after removal of the $\mathrm{CuI}$ matrix.

The authors thank the Deutsche Forschungsgemeinschaft and the Fonds der Chemischen Industrie for financial support. We are grateful to Dr E. Peresypkina (Institute of Inorganic Chemistry, Siberian Division of RAS, Novosibirsk, Russia) for the final solution of the X-ray structure of 6. J. F. N. thanks the Alexander von Humboldt foundation for the award of a Research Prize.

\section{Notes and references}

* Typical experimental procedure: To a solution of CuI (460 mg, $2.59 \mathrm{mmol})$ in $35 \mathrm{ml}$ of $\mathrm{CH}_{3} \mathrm{CN}$ was added tert-butylphosphaalkyne $1(472 \mathrm{mg}$, $4.72 \mathrm{mmol}$ ) under an atmosphere of dry $\mathrm{N}_{2}$. The mixture showed a red colour immediately. ${ }^{31} \mathrm{P}$ NMR spectrum of the solution: $\delta_{\mathrm{P}}(161 \mathrm{MHz}$; $\left.\mathrm{CD}_{3} \mathrm{CN} ; \mathrm{H}_{3} \mathrm{PO}_{4}\right)-58.1$ (s). After a period of 4 days without agitation, orange, microcrystalline $2 \cdot x \mathrm{CH}_{3} \mathrm{CN}(x=1,3)(60 \mathrm{mg}, 7 \%)$ precipitated (Found: $\mathrm{C}, 24.1 ; \mathrm{H}, 4.0 . \mathrm{C}_{20} \mathrm{H}_{37} \mathrm{Cu}_{3} \mathrm{I}_{3} \mathrm{P}_{5}$ requires $\mathrm{C}, 23.9 ; \mathrm{H}, 3.7 \%$ ); $\tilde{v} / \mathrm{cm}^{-1}$ : 1957, 2898, 2861, 1629, 1522, 1473, 1391, 1362, 1260, 1210, 1195, 1087, $1042,1021,1002,930,899,872,795,718,699,584,529,464$. Occasionally a few deep red crystals of $\mathbf{3}$ were also obtained.

$\S$ Two different kinds of crystals for $\mathbf{2}$ were found. Both show the same cage core, but differ in the number of solvent molecules in the crystal lattice. For both structures a $\mathrm{CH}_{3} \mathrm{CN}$ molecule which coordinates to a $\mathrm{Cu}$ atom is found, but in the second structure two additional molecules of $\mathrm{CH}_{3} \mathrm{CN}$ are found in the crystal lattice in between two strands of the coordination polymer. The structure solution of $2 \cdot 3 \mathrm{CH}_{3} \mathrm{CN}$ was not satisfactory due to the poor quality of the crystals obtained (unit cell: $a=$ 11.647(2), $b=13.348(3), c=14.588(3) \AA, \alpha=97.47(3), \beta=103.034(3), \gamma=$ $\left.114.73(3)^{\circ}\right)$. All single crystals were mounted in an inert oil and transferred to the cold stream of a Oxford Diffraction CCD area-detector diffractometer using $\mathrm{Cu}-\mathrm{K} \alpha$ radiation $(\lambda=1.54178 \AA)$. Crystal data for 2. $\mathrm{CH}_{3} \mathrm{CN}: \mathrm{C}_{22} \mathrm{H}_{40} \mathrm{Cu}_{3} \mathrm{I}_{3} \mathrm{NP}_{5}, M=1044.75$, triclinic, space group $P \overline{\mathrm{l}}, a=$ 11.693(2), $b=12.892(2), c=13.172(3) \AA, \alpha=89.99(1), \beta=64.79(2)$, $\gamma=77.48(1)^{\circ}, V=1744.2(6) \AA^{3}, T=103(1) \mathrm{K}, Z=2, \mu(\mathrm{Cu}-\mathrm{K} \alpha)=$ $25.236 \mathrm{~mm}^{-1}, 11103$ reflections measured, 3742 unique $\left(R_{\text {int }}=0.0487\right)$ which were used in all calculations. The final $R_{1}[I>2 \sigma(I)]$ was 0.0368 . Crystal data for $3 \cdot 2 \mathrm{CH}_{3} \mathrm{CN}: \mathrm{C}_{44} \mathrm{H}_{78} \mathrm{Cu}_{4} \mathrm{I}_{4} \mathrm{~N}_{2} \mathrm{P}_{8}, M=1644.64$, monoclinic, space group $P 2_{1} / c, a=15.505(3), b=11.642(2), c=18.001(3) \AA, \beta=$ $111.43(2)^{\circ}, V=3025(1) \AA^{3}, T=104(1) \mathrm{K}, Z=2, \mu(\mathrm{Cu}-\mathrm{K} \alpha)=19.841 \mathrm{~mm}^{-1}$, 13212 reflections measured, 3267 unique $\left(R_{\text {int }}=0.0466\right)$ which were used in all calculations. The final $R_{1}[I>2 \sigma(I)]$ was 0.0391. Crystal data for 6.0.5 $\mathrm{C}_{7} \mathrm{H}_{8}: \mathrm{C}_{23.5} \mathrm{H}_{41} \mathrm{P}_{5}, M=478.41$, monoclinic, space group $C 2 / m, a=$ 23.7888(3), $b=11.2636(2), c=10.3868(1) \AA, \beta=108.202(1)^{\circ}, V=$ 2643.85(6) $\AA^{3}, T=123(2) \mathrm{K}, Z=4, \mu(\mathrm{Cu}-\mathrm{K} \alpha)=3.259 \mathrm{~mm}^{-1}, 25696$ reflections measured, 2385 unique $\left(R_{\text {int }}=0.1366\right)$ which were used in all calculations. The final $R_{1}[I>2 \sigma(I)]$ was 0.0810 . The disordering of the toluene molecule in the crystal lattice of $\mathbf{6}$ over two positions leads to a somewhat elevated $w R_{2}$ value. CCDC 656701-656703. For crystallographic data in CIF or other electronic format see DOI: $10.1039 / \mathrm{b} 712161 \mathrm{j}$

1 G. Becker, G. Gresser and W. Uhl, Z. Naturforsch., Teil B, 1981, 36, 16.

2 J. F. Nixon, Chem. Soc. Rev., 1995, 319.

3 M. Regitz and P. Binger, Angew. Chem., Int. Ed. Engl., 1988, 27, 1484.

4 (a) Phosphorus: The Carbon Copy, ed. K. B. Dillon, F. Mathey and J. F. Nixon, John Wiley, Chichester, 1998; (b) F. Mathey, Angew. Chem., Int. Ed., 2003, 42, 1578.

5 (a) R. Streubel, Angew. Chem., Int. Ed. Engl., 1995, 34, 436; (b) L. Weber, Adv. Organomet. Chem., 1997, 41, 1; (c) A. Mack and M. Regitz, in Carbocyclic and Heterocyclic Cage Compounds and Their Building Blocks, ed. K. K. Laali, J. A. I. Press, Stamford, CT, 1999, p. 199; (d) J. F. Nixon in Carbocyclic and Heterocyclic Cage Compounds and Their Building Blocks, ed. K. K. Laali, J. A. I. Press, Stamford, CT, 1999, p. 257.

6 A. Mack and M. Regitz, Chem. Ber., 1997, 130, 823.

7 (a) P. Kramkowski and M. Scheer, Angew. Chem., Int. Ed., 1999, 38, 3183; (b) P. Kramkowski and M. Scheer, Eur. J. Inorg. Chem., 2000, 1869; (c) D. Himmel, M. Seitz and M. Scheer, Z. Anorg. Allg. Chem., 2004, 630, 1220.

8 J. Bai, A. V. Virovets and M. Scheer, Angew. Chem., Int. Ed., 2002, 41, 1737; J. Bai, E. Leiner and M. Scheer, Angew. Chem., Int. Ed., 2002, 41, 783; J. Bai, A. V. Virovets and M. Scheer, Science, 2003, 300, 781; M. Scheer, L. Gregoriades, J. Bai, M. Sierka, G. Brunklaus and H. Eckert, Chem.-Eur. J., 2005, 11, 2163; M. Scheer, J. Bai, B. P. Johnson, R. Merkle, A. V. Virovets and C. E. Anson, Eur. J. Inorg. Chem., 2005, 4023; M. Scheer, L. J. Gregoriades, A. V. Virovets, W. Kunz, R. Neueder and I. Krossing, Angew. Chem., Int. Ed., 2006, 45, 5689; B. P. Johnson, F. Dielmann, G. Balázs, M. Sierka and M. Scheer, Angew. Chem., Int. Ed., 2006, 45, 2473.

9 For examples of polyphosphorus cages stabilised in a CuI matrix, see: (a) A. Pfitzner and E. Freundenthaler, Angew. Chem., Int. Ed. Engl., 1995, 34, 1647; (b) A. Pfitzner and E. Freundenthaler, Z. Naturforsch., Teil B, 1997, 52, 199.

10 B. Breit, U. Bergsträßer, G. Maas and M. Regitz, Angew. Chem., 1992, 104, 1043; B. Breit and M. Regitz, Chem. Ber., 1996, 129, 489.

11 A. Pfitzner, M. F. Bräu, J. Zweck, G. Brunklaus and H. Eckert, Angew. Chem., Int. Ed., 2004, 43, 4228.

12 P. Binger, S. Leininger, K. Gather and U. Bergsträßer, Chem. Ber., 1997, 130, 1491. 